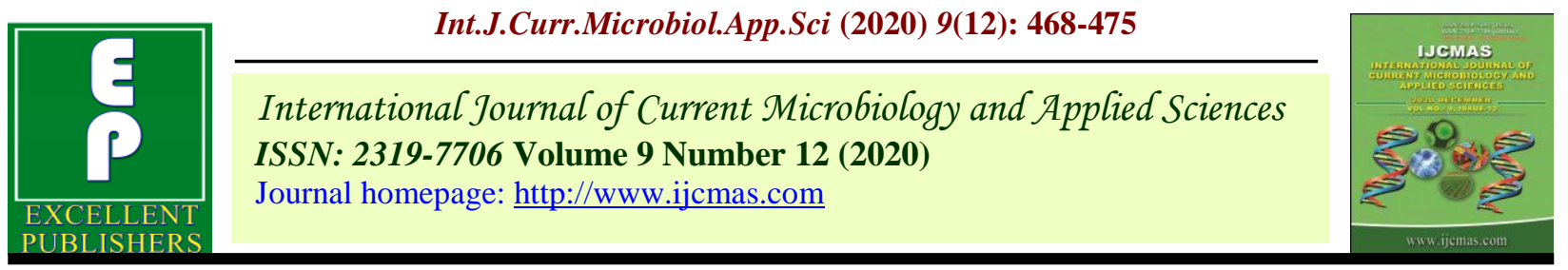

\title{
Irrigation Efficiency and Water Production Function of Furrow Irrigation Influenced by Depth in Wheat Crop
}

\author{
Rahul Dev Kurre*, Surjeet Singh Adile and M. P. Tripathi \\ Deppt of SWE.SVCAET \& RS, FAE, IGKV, Raipur, CG, India \\ *Corresponding author
}

\section{A B S T R A C T}

Keywords

Furrow Irrigation, MAD, Consumptive use, Water production function

Article Info

Accepted:

07 November 2020 Available Online:

10 December 2020
A field study was conducted on irrigation efficiency and water production function in wheat crop at SVCAET and RS IGKV Raipur (C.G). The treatment included were four main treatments of method of Raised bed furrow irrigation $M_{1}\left(15 \mathrm{~cm}\right.$ furrow depth), $M_{2}$ (20 cm furrow depth), $\mathbf{M}_{3}$ (25 cm furrow depth) and $\mathbf{M}_{4}$ (border irrigation system (control)) under the three sub-treatments of maximum allowable depletion (MAD) $\mathrm{T}_{1}$ (Irrigation at $40 \% \mathrm{MAD}$ ), $\mathrm{T}_{2}$ (Irrigation at $50 \% \mathrm{MAD}$ ) and $\mathrm{T}_{3}$ (Irrigation at $60 \% \mathrm{MAD}$ ) in four row crop. These treatments were replicated three times. Strip Plot Design was adopted by considering the moisture depletion and method of furrow irrigation as treatment. Mean water application efficiency was found maximum under M2 treatment. However maximum water distribution efficiency found under M1 then M2.The water use efficiency recorded maximum $\left(9.50 \mathrm{~kg} \mathrm{ha}^{-1} \mathrm{~mm}^{-1}\right.$ ) under M2T2. Similarly in border system maximum $\left(8.98 \mathrm{~kg} \mathrm{ha}^{-1} \mathrm{~mm}^{-1}\right)$ recorded in M4T2.

\section{Introduction}

Water is one of the most essential natural resources for sustaining life and it is likely to become critically scarce in the coming decades, due to continuous increase in its demands, rapid increase in population and expanding economy of the country.

Water is becoming increasingly scarce due to growing demand in the domestic and industrial sectors so there is a need to develop water saving irrigation techniques that require less irrigation input than the traditional method. There is a new method of wheat sowing in which wheat is sown on raised beds called FIRB (Furrow Irrigated Raised Bed) system. This method is being followed in many wheat growing countries. Bed planting of wheat helps in saving of 25-30\% water and reducing costly herbicide application by mechanical weeding of grassy weeds (Gill and Jat, 2007).

Furrow Irrigated Raised Bed irrigation system consists of alternate furrows and flat beds in ridges. Better irrigation efficiency can be achieved by adopting the bed and furrow irrigation technique for growing of wheat and other row crops, with many benefits over conventional basin irrigation methods. 


\section{Materials and Methods}

A fields experiments was conducted at the Research Farm of SVCAET\&RS, IGKV, Raipur, CG during the rabi season. The bulk density of the soil was $1.48 \mathrm{~g} / \mathrm{cm}^{3}$, field capacity was $27 \%$, permanent wilting point was $13.15 \%$ and the basic infiltration rate of the soil was $0.58-0.66 \mathrm{~cm} / \mathrm{hr}$. The irrigation efficiency and water production function in wheat crop were studied in furrow irrigated raised bed with variable furrow sections under three moisture regimes, viz. Irrigation at 40, 50 and 60\% MAD (Maximum Allowable Depletion). In this system, three different depth of furrow at 15,20 and $25 \mathrm{~cm}$ were made and the four row of crops at $22.5 \mathrm{~cm}$ were planted on top of each bed (Fig. 1). Strip plot design was adopted by considering the moisture depletion and method of furrow irrigation as treatments. These were compared with border irrigation method. Irrigation water was applied in furrows.

\section{Irrigation efficiency}

Irrigation efficiency is the effectively utilization of the available water supply in different methods of irrigation. Proper field preparation, design of irrigation system and the skill of irrigator are the most common factor which increases irrigation efficiency.

\section{Water application efficiency}

Water application efficiency is the measurement of efficiently water applied from field channel to field and defined as follows (Michael, 1978):

$$
\mathrm{E}_{\mathrm{a}}=\frac{W_{s}}{W_{f}} \times 100
$$

Where,

$\mathrm{E}_{\mathrm{a}}=$ water application efficiency, $(\%)$
$\mathrm{W}_{\mathrm{s}}=$ water stored in the root zone of the plant $\mathrm{W}_{\mathrm{f}}=$ water delivered to the field (at the field supply channel)

\section{Water storage efficiency}

Water storage efficiency relates how completely the water needed prior to irrigation has been stored in the root zone during irrigation. It is defined as:

$\mathrm{E}_{\mathrm{S}}=\frac{w_{s}}{w_{n}} \times 100$

Where,

$\mathrm{E}_{\mathrm{S}} \quad=\quad$ water storage efficiency $(\%)$

$\mathrm{W}_{\mathrm{s}}=$ water stored in the root zone during irrigation

$\mathrm{W}_{\mathrm{n}}=$ water needed in the root zone prior to irrigation

\section{Water production function}

The relationship between water use efficiency and grain yield was developed for water production function.

\section{Consumptive use}

Consumptive use, often called evapotranspiration, is the amount of water used by the vegetative growth of a given area in transpiration and building up of plant tissues and evaporation from soil and plant surfaces. Since the difference between evapotranspiration and consumptive use is usually less than $1 \%$. It is assumed equal to be ET.

Seasonal consumptive use $\left(\mathrm{C}_{\mathrm{u}}\right)$ is calculate from the following relationship:

$C_{u}=\sum_{K=1}^{N}\left(E_{0} \times 0.8\right)+\sum_{i=1}^{n} \frac{M_{1} i-M_{2} i}{100} A i \cdot D_{i}+E_{R}$ 
Where,

$\mathrm{C}_{\mathrm{u}}=$ Seasonal consumptive use in

$\mathrm{mm}$

$\mathrm{N}=$ Number of layers samples in root zoon depth $\mathrm{D}$,

$\mathrm{M}_{1} \mathrm{i}=$ Soil moisture percent at the time of first sampling in $i^{\text {th }}$ layer,

$\mathrm{M}_{2} \mathrm{i}=$ Soil moisture percent at the time of second sampling in $i^{\text {th }}$

layer,

$\mathrm{Ai}=$ Apparent specific gravity of the $i^{\text {th }}$ layer of the soil,

$D_{i} \quad=\quad$ Depth of $i^{\text {th }}$ layer of the soil in

$\mathrm{mm}$,

$\mathrm{E}_{\mathrm{R}}=$ Effective rainfall

$\mathrm{N}=$ Time interval in days

$\mathrm{E}_{0}=$ Pan evaporation in $\mathrm{mm}$ from

day of irrigation to day when

Soil samples were taken in wet soil.

\section{Water Use Efficiency (WUE)}

Eventually water use efficiency of crop has been expressed as the ratio of grain yield $(\mathrm{kg}$ $\left.\mathrm{ha}^{-1}\right)$ to the consumptive use (mm) of crop(Michael, 1978):

$\mathrm{WUE}=\frac{\text { Grain yield }(\mathrm{kg} / \mathrm{ha})}{\text { consumptive use }(\mathrm{mm})}$

\section{Results and Discussion}

\section{Irrigation efficiencies}

Irrigation efficiency is one of the major factor which indicates the performance of the irrigation system. Water application, distribution and water storage efficiencies were calculated in this study.

\section{Water application efficiency}

The mean water application efficiency varied from 52.76 to 66.14. per cent (Table 1). The maximum value of water application efficiency was measured 66.14 per cent in 20 $\mathrm{cm}$ furrow depth and minimum value were recorded 62.46 per cent in $15 \mathrm{~cm}$ furrow depth. In border irrigation system water application efficiency was 52.76 percent recorded (Fig. 2).

\section{Water storage efficiency}

Water storage efficiency was recorded maximum (60.53 per cent) in $25 \mathrm{~cm}$ furrow depth treatment. The efficiency was found minimum (57.5 per cent) in $15 \mathrm{~cm}$ furrow depth treatment (Table 2).

The mean water storage efficiency varied from 57.50 to 60.53 per cent in furrow irrigated raised bed system. In furrow irrigated raised bed system $25 \mathrm{~cm}$ furrow depth recorded maximum efficiency than the 15 and $20 \mathrm{~cm}$ furrow depth. In the border irrigation system the water storage efficiency was approximately same as $25 \mathrm{~cm}$ furrow depth treatment. The mean water storage efficiency has been shown in Fig 3.

\section{Water distribution efficiency}

The mean water distribution efficiency varied from 94.07 to 89.74 per cent. The mean maximum (94.07 per cent) water distribution efficiency was recorded under $15 \mathrm{~cm}$ furrow depth and the minimum (89.74 per cent) recorded in $25 \mathrm{~cm}$ furrow depth (Table 3 ).

Water application, storage and distribution efficiencies for different treatments have been shown graphically in Fig. 4. to depict overall effect of individual treatment on these efficiencies. It can be seen from the Fig. 5 that the water application efficiency was observed the highest in $25 \mathrm{~cm}$ furrow depth while the water storage efficiency and distribution efficiency ware found maximum in $15 \mathrm{~cm}$ furrow depth and $25 \mathrm{~cm}$ furrow depth comparatively border irrigation system. 
Table.1 Water application efficiency of irrigation

\begin{tabular}{|c|c|c|c|c|}
\hline \multirow{2}{*}{ Irrigation system } & \multicolumn{4}{|c|}{ Water application efficiency } \\
\cline { 2 - 5 } & I Irrigation & II Irrigation & III Irrigation & Mean \\
\hline M1 & 62.41 & 61.24 & 63.72 & 62.46 \\
\hline M2 & 65.55 & 66.47 & 66.41 & 66.14 \\
\hline M3 & 64.59 & 64.52 & 65.14 & 64.75 \\
\hline M4 & 52.87 & 50.95 & 54.45 & 52.76 \\
\hline
\end{tabular}

Table.2 Water storage efficiency of irrigation

\begin{tabular}{|c|c|c|c|c|}
\hline \multirow{2}{*}{ Irrigation } & \multicolumn{4}{|c|}{ Water storage efficiency } \\
\cline { 2 - 4 } & I Irrigation & II Irrigation & III Irrigation & Mean \\
\hline M1 & 57.92 & 59.12 & 55.48 & 57.50 \\
\hline M2 & 59.52 & 59.89 & 58.25 & 59.22 \\
\hline M3 & 58.65 & 60.37 & 62.59 & 60.53 \\
\hline M4 & 60.52 & 59.89 & 61.28 & 60.56 \\
\hline
\end{tabular}

Table.3 Water distribution efficiency

\begin{tabular}{|c|c|c|c|c|}
\hline \multirow{2}{*}{ Irrigation } & \multicolumn{4}{|c|}{ Water storage efficiency } \\
\cline { 2 - 5 } & I Irrigation & II Irrigation & III Irrigation & Mean \\
\hline M1 & 93.25 & 94.12 & 94.85 & 94.07 \\
\hline M2 & 90.24 & 89.47 & 93.14 & 90.95 \\
\hline M3 & 88.48 & 90.28 & 90.47 & 89.74 \\
\hline M4 & 80.47 & 78.63 & 80.74 & 79.95 \\
\hline
\end{tabular}

Table.4 Seasonal consumptive use and water use efficiency under different treatments

\begin{tabular}{|c|c|c|}
\hline Treatment & $\begin{array}{c}\text { Seasonal Consumptive use } \\
(\mathrm{mm})\end{array}$ & $\begin{array}{c}\text { Water use efficiency }\left(\mathrm{kg} \mathrm{ha}^{-1}\right. \\
\left.\mathrm{mm}^{-1}\right)\end{array}$ \\
\hline M1T1 & 369.45 & 5.66 \\
\hline M2T1 & 372.42 & 6.24 \\
\hline M3T1 & 362.12 & 6.52 \\
\hline M4T1 & 288.00 & 6.72 \\
\hline M1T2 & 278.00 & 8.48 \\
\hline M2T2 & 296.45 & 9.50 \\
\hline M3T2 & 283.00 & 9.17 \\
\hline M4T2 & 284.90 & 8.98 \\
\hline M1T3 & 256.10 & 5.08 \\
\hline M2T3 & 252.21 & 7.54 \\
\hline M3T3 & 246.00 & 7.12 \\
\hline M4T3 & 251.40 & 6.48 \\
\hline
\end{tabular}


Fig.1 15, 20 and $25 \mathrm{~cm}$ depth of furrow irrigated raised bed system
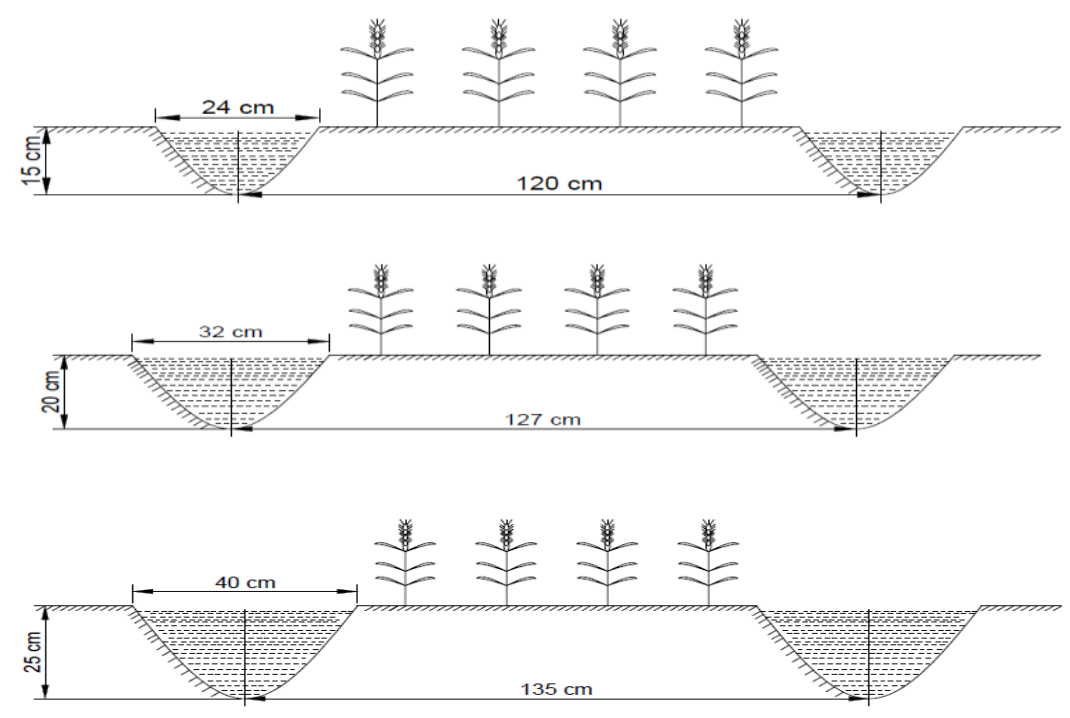

Fig.2 Mean water application efficiency

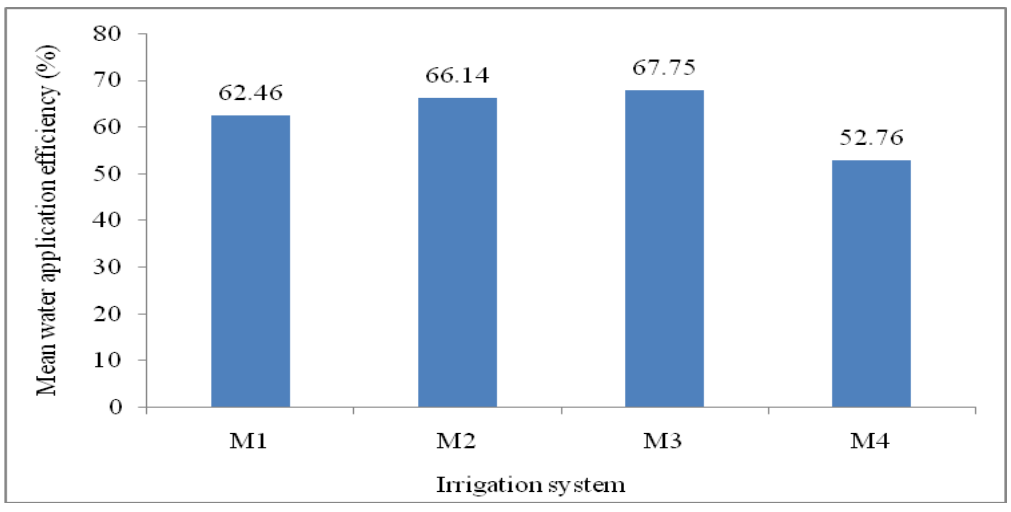

Fig.3 Mean water storage efficiency

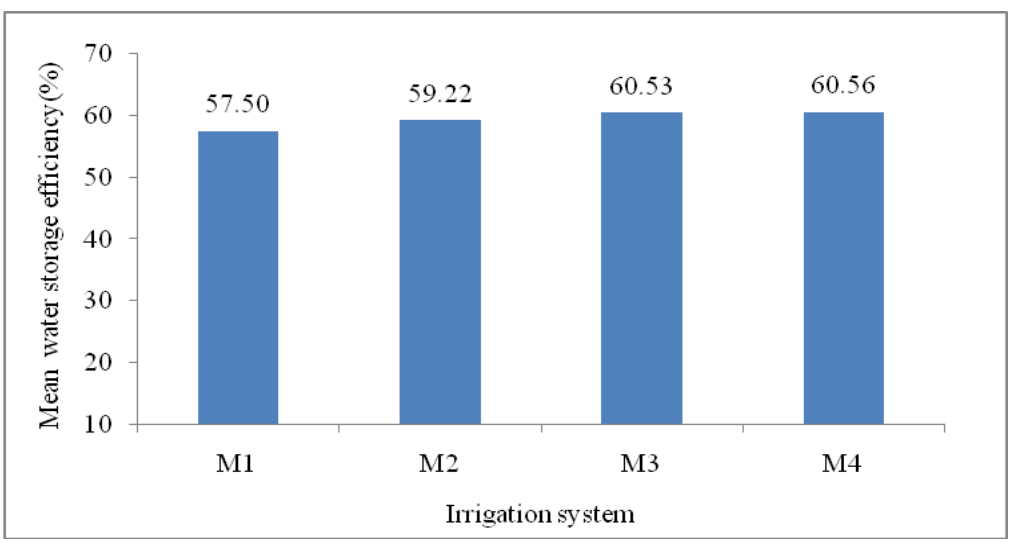


Fig.4 Mean water distribution efficiency

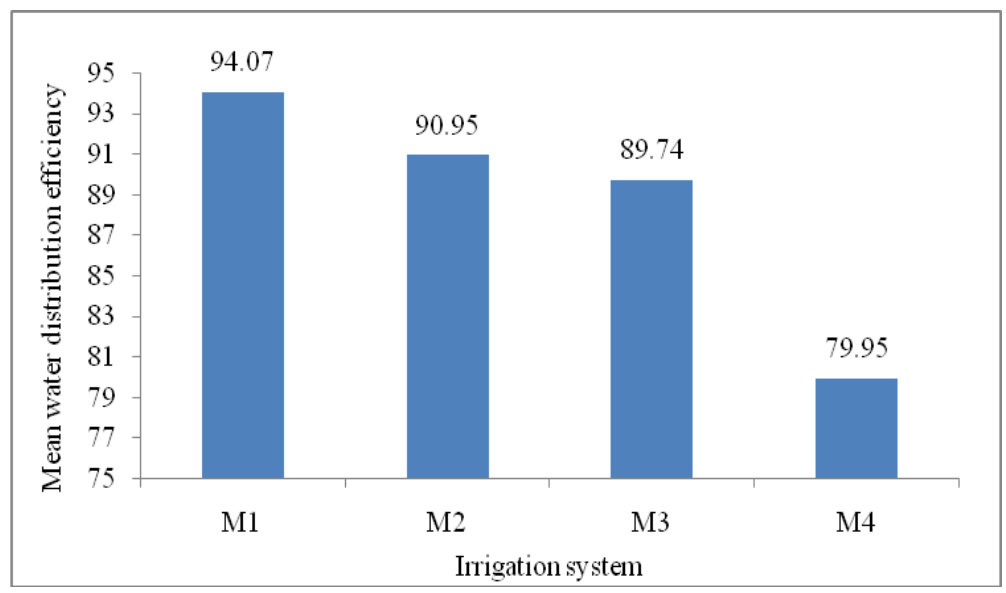

Fig.5 Water application efficiency (W Ea), storage efficiency (W Es) and distribution efficiency (W Ed) for different treatment

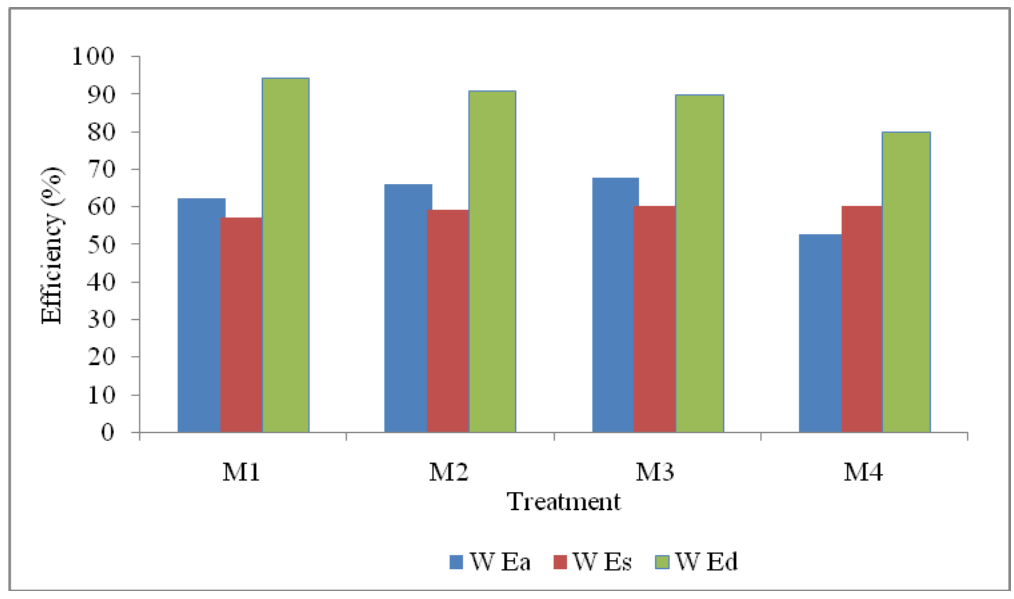

Fig.6 Seasonal consumptive use and water use efficiency

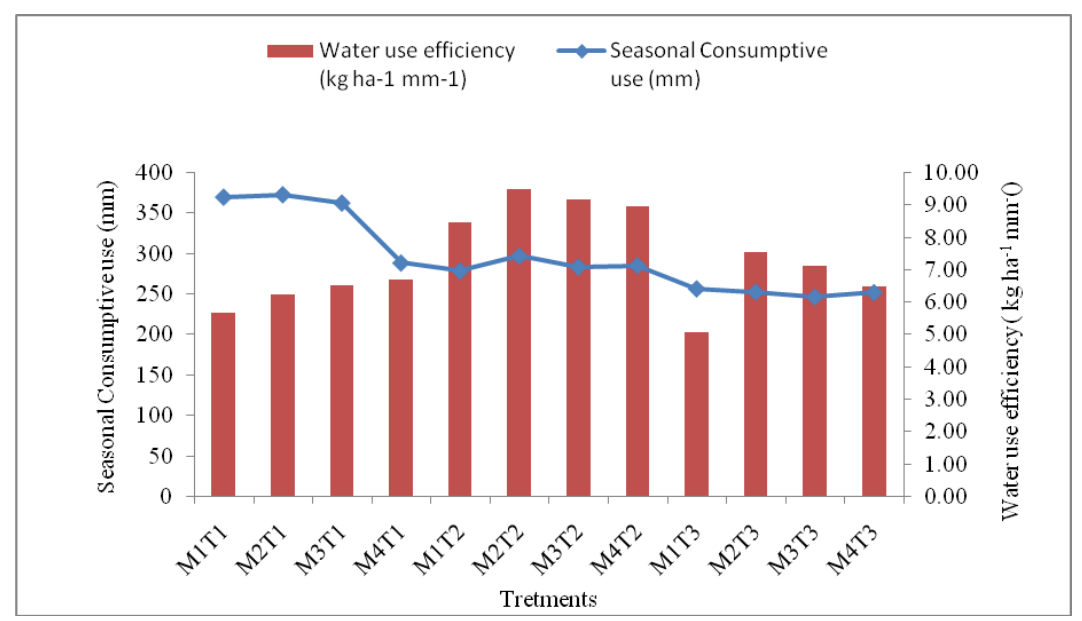




\section{Water production function}

\section{Consumptive use}

The seasonal water supply is determined and evaluated by the seasonal water use efficiency. Consumptive use for furrow irrigated raised bed system and borders was estimated by moisture depletion method. The moisture depletion from sowing to harvesting was calculated.

The moisture depletion for the days between irrigation applied and moisture samples taken was considered 0.8 of pan evaporation. The seasonal consumptive use varied between 246.00 to $372.42 \mathrm{~mm}$. In furrow irrigated raised bed system $20 \mathrm{~cm}$ furrow depth at $40 \%$ MAD treatment recorded the highest value $(372.42 \mathrm{~mm})$. In border irrigation method treatment at $40 \%$ MAD recorded highest value $(288.00 \mathrm{~mm})$ (Fig. 6 and Table 4).

\section{Water use efficiency}

The water use efficiency varied from 5.08 to $9.50 \mathrm{~kg} \mathrm{ha}^{-1} \mathrm{~mm}^{-1}$ for furrow irrigated raised bed system and similarly for border it varied from 6.48 to $8.98 \mathrm{~kg} \mathrm{ha}^{-1} \mathrm{~mm}^{-1}$. In furrow irrigated raised bed system the maximum water use efficiency found in $9.50 \mathrm{~kg} \mathrm{ha}^{-1}$ $\mathrm{mm}^{-1}$ in $20 \mathrm{~cm}$ furrow depth under 50\% MAD and minimum recorded in $15 \mathrm{~cm}$ furrow depth under $60 \%$ MAD $\left(5.08 \mathrm{~kg} \mathrm{ha}^{-1} \mathrm{~mm}^{-1}\right)$. In border irrigation Highest $\left(8.98 \mathrm{~kg} \mathrm{ha}^{-1} \mathrm{~mm}^{-1}\right)$ recorded in 50\% MAD and minimum (6.48 $\mathrm{kg} \mathrm{ha}^{-1} \mathrm{~mm}^{-1}$ ) in $40 \%$ MAD.

Thus it can be concluded that the data presented from the research shows that the seasonal consumptive use varied between 246.00 to $372.42 \mathrm{~mm}$. In furrow irrigated raised bed system $20 \mathrm{~cm}$ furrow depth at $40 \%$ MAD treatment recorded the highest value $(372.42 \mathrm{~mm})$. In border irrigation method treatment at $40 \%$ MAD recorded highest value $(288.00 \mathrm{~mm})$. The water use efficiency varied from 5.08 to $9.50 \mathrm{~kg} \mathrm{ha}^{-1} \mathrm{~mm}^{-1}$ for furrow irrigated raised bed system and similarly for border it varied from 6.48 to $8.98 \mathrm{~kg} \mathrm{ha}^{-1} \mathrm{~mm}^{-1}$.

In furrow irrigated raised bed system the maximum water use efficiency found in 9.50 $\mathrm{kg} \mathrm{ha}^{-1} \mathrm{~mm}^{-1}$ in $20 \mathrm{~cm}$ furrow depth under $50 \%$ MAD and minimum recorded in $15 \mathrm{~cm}$ furrow depth under 60\% MAD $\left(5.08 \mathrm{~kg} \mathrm{ha}^{-1}\right.$ $\left.\mathrm{mm}^{-1}\right)$. In border irrigation Highest $(8.98 \mathrm{~kg}$ $\mathrm{ha}^{-1} \mathrm{~mm}^{-1}$ ) recorded in 50\% MAD and minimum (6.48 $\left.\mathrm{kg} \mathrm{ha}^{-1} \mathrm{~mm}^{-1}\right)$ in 40\% MAD.

Saving in irrigation water was calculated over the treatments from total depth of applied water. The maximum water saving was obtained $8.33 \mathrm{~cm}$ furrow irrigated raised bed system and $4.02 \mathrm{~cm}$ in border system in 50\% MAD treatment over 40\% MAD. Similarly, the maximum water saving was obtained 5.61 $\mathrm{cm}$ furrow irrigated raised bed system and $3.39 \mathrm{~cm}$ in border system in 60\% MAD treatment over 50\% MAD.

\section{References}

Hodges, Mark E., Stone, J.F., Garton, J.E. and Weeks, D.L. 1989a. Yield variability and water use in wide spaced furrow irrigation. Agricultural water management, 16:15-23.

Jat, Laxmi Narayan. 2001. Evaluation of FIRB planting system for development of productive and sustainable wheat based cropping system. Ph.D. Thesis, Department of Agronomy, Rajasthan College of Agriculture, Udaipur.

Michael, A.M. 1978. Irrigation Theory and Practices. Vikas Publishing House Pvt. Ltd., New Delhi. Pp. 610-622.

Pandey, Devesh, Parihar, S.S., Verma, V.K. and Sharma, R.B. 1997. Crop production factor models for wheat crop under water stress condition. Journal of 
Indian Water Resource Society17: 3941.

Singh, Raxpal. 1994. Optimal irrigation scheduling for wheat crop in Udaipur region. M.E. Thesis, Department of soil and Water Conservation Engg., College of Technology and Udaipur, Rajasthan.

\section{How to cite this article:}

Rahul Dev Kurre, Surjeet Singh Adile and Tripathi, M. P. 2020. Irrigation Efficiency and Water Production Function of Furrow Irrigation Influenced by Depth in Wheat Crop. Int.J.Curr.Microbiol.App.Sci. 9(12): 468-475. doi: https://doi.org/10.20546/ijcmas.2020.912.057 